\title{
Effects of Physical Parameters on Bacterial Cell Adsorption onto Pre-Imprinted Sol-Gel Films
}

\author{
Jeanna Starosvetsky ${ }^{1}$, Tally Cohen ${ }^{1}$, Uta Cheruti $^{1}$, Dragoljub Bilanović $^{2}$, Robert Armon ${ }^{1 *}$ \\ ${ }^{1}$ Faculty of Civil and Environmental Engineering Division of Environmental, Water and Agricultural Engineering, Technion, Haifa, \\ Israel; ${ }^{2}$ Center for Environmental, Earth, and Space Studies, Bemidji State University, Bemidji, USA. \\ Email: ${ }^{*}$ cvrrobi@tx.technion.ac.il
}

Received April 30 ${ }^{\text {th }}, 2012$; revised June $15^{\text {th }}, 2012$; accepted July $16^{\text {th }}, 2012$

\begin{abstract}
Organically modified silica (ORMOSILS) thin films produced by sol-gel method were imprinted with two bacterial strains as whole cells in order to develop an easy, fast and specific probe to detect and specifically identify these microorganisms when present in water samples. An important feature of the imprinting process was the molecular fingerprints left by these microorganisms alongside morphology, into imprinted film cavities. The films also showed high selectivity toward the imprinted template and were able to discriminate between two very close bacterial species (E. coli and S. typhimurium). In addition, several central physical parameters of the experimental water solution were examined (i.e., $\mathrm{pH}$, ionic strength and the organic load exemplified by $\mathrm{NaCl}$ and $\mathrm{TOC}$ concentration, respectively). The method sensitivity to different bacterial concentrations was studied by confocal microscopy (CLSM) and quartz crystal microbalance (QCM) tools. Results showed that increased bacterial concentrations favor rapid adsorption onto imprinted sol-gel films with high affinity, while low $\mathrm{pH}$, increased organic load and high ionic concentrations (i.e., seawater) interfere with bacteria re-adsorption, reducing detection capability. Under average drinking water chemical composition the method proved to be highly efficient.
\end{abstract}

Keywords: Detection; Imprinting; Sol-Gel; Bacteria; QCM; E. coli O157:H7; S. typhimurium; Sphaerotilus natans; CLSM

\section{Introduction}

The source of $80 \%$ of gastrointestinal illnesses in developing countries is caused by consumption of polluted drinking water. As already pointed out, "waterborne disease probably accounts for more than 2.5 million death/ year with a majority of children under 5 years of age" [1]. In view of this fact, rapid, economic and accurate identification and quantification of indicator or pathogenic microorganisms present in these environments is a necessity for public health improvement.

There are a number of current methods to identify and quantify bacteria in water in routine use, practiced by most of water laboratories around the globe. For example, MPN (most probable number) is the method that provides a statistic estimate of viable and culturable bacterial cell numbers [2]. The technique is applicable to all kinds of samples, however it is most advantageous in turbid and marine waters were direct filtration may be hindered. Variations of this method have been developed for all faecal indicator bacteria in question: E. coli, coliforms, enterococci, bacteriophages and C. perfringens

${ }^{*}$ Corresponding author.
[3-5]. However, the main drawback of this method is that MPN procedure demands long incubation time and large incubator space due to the numerous experimental tubes required. Another highly used method is membrane filtration (MF), an alternative method for identification and quantification of bacteria present in water samples [2]. Following capture of bacteria onto membrane surface, the filter is placed onto various selective media and the detection of specific microorganisms is possible by development of visible colonies under the restriction of discriminatory substrates. The final result is expressed by colonies growth coupled with color development. The newly developed colonies are counted and identified based on biochemical tests or genotypically by polymerase chain reaction (PCR) and electrophoresis [3]. The MF method in spite of its global acceptance in water microbiology laboratories still has several drawbacks: relatively long incubation times, occasionally false positive results and requirement for relatively clear water samples.

Based on specific and different biochemical pathways of bacteria, other methods were developed (i.e., Colilert) but still presenting sometimes false positive/negative 
results or yet relatively long time [6].

Consequently based on this knowledge, there is a need for a rapid, efficient, relatively simple and inexpensive method for detection of microorganisms present in water. Cohen et al. [7] showed that macromolecular imprinting of sol-gel surfaces with specific bacteria provides an interesting mean of bacteria detection in liquid samples.

Molecular imprinting is a method in which an appropriate functional monomer is polymerized in the presence of a template forming covalent or non-covalent bonds with the functional monomer [8]. Afterward, following polymerization process, the template is removed that leaves a space or cavity originally occupied by the template molecule, in its original shape. These cavities due to their steric shape can adopt and bind similar or analogous molecule with pronounced selectivity and sensitivity [9]. The next step in this interesting methodology was to imprint much more complex organic structures such as whole cells in sol-gel matrices, termed macromolecular imprinting [7].

The imprinting of whole cells into inorganic sol-gel matrices has been practiced for the past fifteen years, pioneered by the study of Carturan et al., [10] who encapsulated S. cerevisiae yeast into silica gel and studied its catalytic activity. Barreau et al. [11] and Livage [12] showed that entrapment of parasitic protozoa in sol-gel does not affect cells' structure. Imprinting of whole cells in sol-gel was reported by Chia [13], and further developed by Dickert $[14,15]$. These authors manufactured a polyurethane surface imprinted with $S$. cerevisiae yeasts allowing a selective and highly sensitive enrichment of the microorganisms under flow conditions. As already shown in previous studies, different types of microorganisms can also be detected by molecular imprinted polymers $[7,15,16]$. Detection and quantification of whole yeast cells imprinted on films made of polyurethane and alkoxide through sol-gel technique was obtained by application of QCM [14].

Bacteria and viruses are very small microorganisms (in the range of $1-3 \mu \mathrm{m}$ and 30 to $700 \mathrm{~nm}$, respectively) that behave as colloidal particles in aqueous systems and therefore can be considered as living colloids. Due to their colloidal behavior, many biological aspects of their adsorption on surfaces can be explained in terms of their physicochemical properties. It is not clear whether the primary factors controlling the degree of bacterial association with surfaces are related to solid interface capacity to support growth, strictly to physicochemical interactions or to some permutation of these factors [17]. In a previous study it was shown that imprinted bacteria onto sol-gel surfaces created cavities that allowed for a secondary adsorption of similar bacteria, based on steric similarity [7]. The present research was aimed to reveal the solution physicochemical properties' effect on the re-adsorption of bacteria onto imprinted sol-gel surface. Among these parameters bacterial cells and $\mathrm{NaCl}$ concentration, $\mathrm{pH}$, TOC were assessed for their impact on the specific adsorption of bacteria to whole-cell-imprinted sol-gel thin films, through live cell imaging (confocal microscopy) and quartz crystal microbalance as evaluating tools.

\section{Materials and Methods}

\subsection{Bacterial Cultures}

Two members of the family Enterobacteriaceae were used in the present study: E. coli and Salmonella typhimurium. The first one was selected as a model of indicator bacteria (E. coli $\mathrm{CN}_{13}$ ) and as a known pathogen (E. coli $\mathrm{O} 157: \mathrm{H7}$ ) while the second member is a known pathogen with phenotypic and genotypic close similarity to the first one (S. typhimurium).

E. coli $\mathrm{CN}_{13}$ (an E. coli $\mathrm{C}$ that lacks restriction system against bacteriophages and harbors nalidixic acid resistance, isolated in our laboratory was grown in nutrient broth (Difco, USA) for 16 hours at $35^{\circ} \mathrm{C} \pm 1{ }^{\circ} \mathrm{C}$ [18]. The grown culture was further centrifuged for 10 minutes at $6000 \mathrm{x}$ g (Sorvall T 6000D). Supernatant medium was discarded and concentrated cells were washed twice with saline $(0.85 \%)$ and finally resuspended in saline. S. typhimurium (ATCC 14028) (G-) was grown on McConkey agar (Difco, USA) for 16 hour at $35^{\circ} \mathrm{C} \pm 1^{\circ} \mathrm{C}$. Grown colonies were harvested and washed similarly to $\mathrm{E}$. coli $\mathrm{CN}_{13}$ and suspended in saline. E. coli O157:H7 was grown on $\mathrm{R}_{2} \mathrm{~A}$ agar (Acumedia, USA) for 16 hours at $35^{\circ} \mathrm{C}$, harvested and suspended in saline.

\subsection{Sol-Gel Thin Films}

Sol gel solution and thin films were prepared as already described $[7,19,20]$. Briefly, a tetraethoxysilane (TEOS, 98\%, ABCR Co., Germany) precursor was used as bulk sol-gel solution. TEOS $(2 \mathrm{ml})$ was mixed with tripledistilled water $(1 \mathrm{ml})$ and gently stirred for $10 \mathrm{~min}$ at room temperature $\left(22^{\circ} \mathrm{C} \pm 1^{\circ} \mathrm{C}\right)$. Next, $0.1 \mathrm{M} \mathrm{HCl}(0.1 \mathrm{~N}$, $0.25 \mathrm{ml}$ ) was added to the solution which was further stirred for $3-5$ hours until visible homogeneity. The final solution was aged at $4{ }^{\circ} \mathrm{C} \pm 1{ }^{\circ} \mathrm{C}$ for 24 hours and kept for approximately 5 weeks at $4^{\circ} \mathrm{C}$.

\subsection{Macromolecular Imprinting Procedure}

Sol-gel films (SG) were prepared on standard microscope glass slides previously cleaned according to a modified procedure [7]. Briefly, glasses were soaked for 20 - 30 min successively in 1:1:1 acetone-ethanol-chloroform mixture; soap solution; Piranha solution: $\mathrm{H}_{2} \mathrm{SO}_{4}: \mathrm{H}_{2} \mathrm{O}_{2}$ (4:1), subsequently exhaustively rinsed in double-distilled water and finally dried at $100^{\circ} \mathrm{C}$ for $2-4$ hours. 
The imprinting procedure was as following: aged solgel stock solution $(0.5 \mathrm{ml})$ was added to a bacterial suspension $\left(3 \mathrm{ml}, 10^{9}-10^{10} \mathrm{CFU} / \mathrm{ml}\right)$ and stirred for 8 to 10 minutes. Subsequently a glass slide was drop-coated with $0.25 \mathrm{ml}$ of the experimental mixture. To obtain a thin and uniform film, the glass slide was immediately positioned vertically to drain excess solution. Slides coated with sol-gel films containing live bacteria were placed into a desiccator and dried overnight at room temperature. Removal of immobilized bacterial cells from dried sol-gel film was performed by soaking the coated slides for 30 $40 \mathrm{~min}$ in $96 \%$ ethanol and washed with sterile double-distilled water. Slides were further Gram stained (successively $3 \mathrm{~min}$ in crystal violet, iodine, 70\% ethanol, safranin for 3 minutes each) (Bactolab Diagnostics, Israel) to visually detect cavities formed by entrapped bacteria (Figure 1(A)). It is important to note that in many cases immobilized bacterial cells dropped just after Gram staining procedure short of ethanol treatment.

\subsection{Confocal Microscopy (CLSM)}

In order to monitor the adsorption process with free live bacteria, live imaging was performed on Leica CLSM microscope. Pre-cut and imprinted microscopic slides were glued to Petri dish and let dry for 2 hours. A water dip objective lens $(\times 63)$ was used for confocal brightfield scan, in altered solutions, for example: different bacteria concentrations $\left(10^{2}-10^{7}\right.$ cells $\left./ \mathrm{ml}\right)$, various $\mathrm{pH}-\mathrm{s}$ $(2.5,5.3$ and 7.5), TOC $(1.3,13$ and $60 \mathrm{mg} / \mathrm{ml})$ and $\mathrm{NaCl}$ concentrations $(1.4,140$ and $300 \mathrm{mM})$.

All experiments were performed with a culture of $E$. coli $\mathrm{CN}_{13}$ pre-stained with $0.001 \mathrm{gr} / \mathrm{ml}$ methylene blue (Spectrum, USA) for 10 minutes, washed twice by centrifugation with $0.85 \%$ saline to reach a concentration of $\sim 1-4 \times 10^{7}$ cells $/ \mathrm{ml}$ (counted with hemocytometer). In a small petri dish, $1 \mathrm{ml}$ of bacterial suspension was added to $5 \mathrm{ml}$ solution and a scan was made every 30 seconds, for the duration of one hour. Cell adhesion count was performed on each frame.

\subsection{Immunofluorescence}

In order to discriminate between the two enterobacterial strains (E. coli $\mathrm{O} 157: \mathrm{H} 7$ and S. typhimurium) immunofluorescence was applied. Thin films imprinted with either strain were prepared as mentioned above. Entrapped bacteria were removed, and both types of the imprinted films were exposed to Salmonella typhimurium, E. coli, or a mixed suspension $\left(10^{7} \mathrm{cell} / \mathrm{ml}\right.$ mixed culture with identical concentration of both bacterial strains). Attachment of bacteria to cavities formed on the imprinted film surface was detected by immunofluorescence. Cells were fixed with $4 \%$ formaldehyde, washed with cold PBS buffer and blocked with bovine serum albumin (BSA) (1\% BSA in PBS) for four hours. Cells were detected by specific antibodies. E. coli O157:H7 was detected with specific antibody (Goat anti E. coli, Zotal, Israel) conjugated with FITC (fluoresceinisothiocyanate, excitation/emission-488/520 nm). S. typhimurium was detected with primary antibody (mouse monoclonal to S. typhimurium, Zotal, Israel) and a secondary antibody (Goat anti mouse, affinity purified, Zotal, Israel) conjugated with DyLight $594^{\circ}$ (excitation/emission-593/ 618). Primary antibodies were incubated at room temperature overnight and washed with PBS. Secondary antibodies were incubated for two hours at room temperature and washed with PBS. Microscopical observations were performed with Leica Confocal microscope (CLSM) in dual channel state.

\subsection{QCM Measurements Procedure}

Sensitivity assessment of the imprinted sol-gel films for their respective bacterial cells was performed by measurements within a flow cell connected to quartz crystal microbalance apparatus (QCM922, Princeton Applied Research). Measurements were made on gold electrode equipped with $9 \mathrm{MHz}$ quartz crystals. Thin film coated crystals were prepared by smear-coating procedure with sol-gel stock solution mixed with bacterial suspension $(0.85 \%$ saline) following over-night desiccation. Immobilized bacterial cells removal from cured sol-gel film was performed by coated crystals immersion in ethanol (96\%) for 30 to 40 minutes and additional rinse with sterile double distilled water (SDDW). Control crystals were coated with sol-gel films without imprinted bacteria (termed non-imprinted film) and rinsed with suspension medium $(0.85 \% \mathrm{NaCl} \mathrm{w} / \mathrm{v}+0.2 \%$ Tween- $80, \mathrm{v} / \mathrm{v})$.

The coated crystals (imprinted and non-imprinted) were exposed to UV lamp for 10 minutes, to attain steady measurements. Subsequently, the crystals were inserted in the flow cell and rinsed with SDDW. Once a stable measurement with SDDW was reached, the crystals were washed with the basic solution for additional 20 minutes and finally exposed to experimental bacterial solution accordingly. Measurements were performed by flow of different solutions containing different concentrations of bacteria over the detector (flow cell, $0.5 \mathrm{ml} /$ minute, ColeParmer Masterflex L/S pump).

\section{Results and Discussion}

\subsection{Method's Selectivity}

In an earlier study it was shown that imprinted sol-gel films differentiate between types of microorganisms based on shape and size variation and only cavities-specific adsorption takes place (Figures 1(A) and (B)) [7]. In the present study different techniques were applied in 

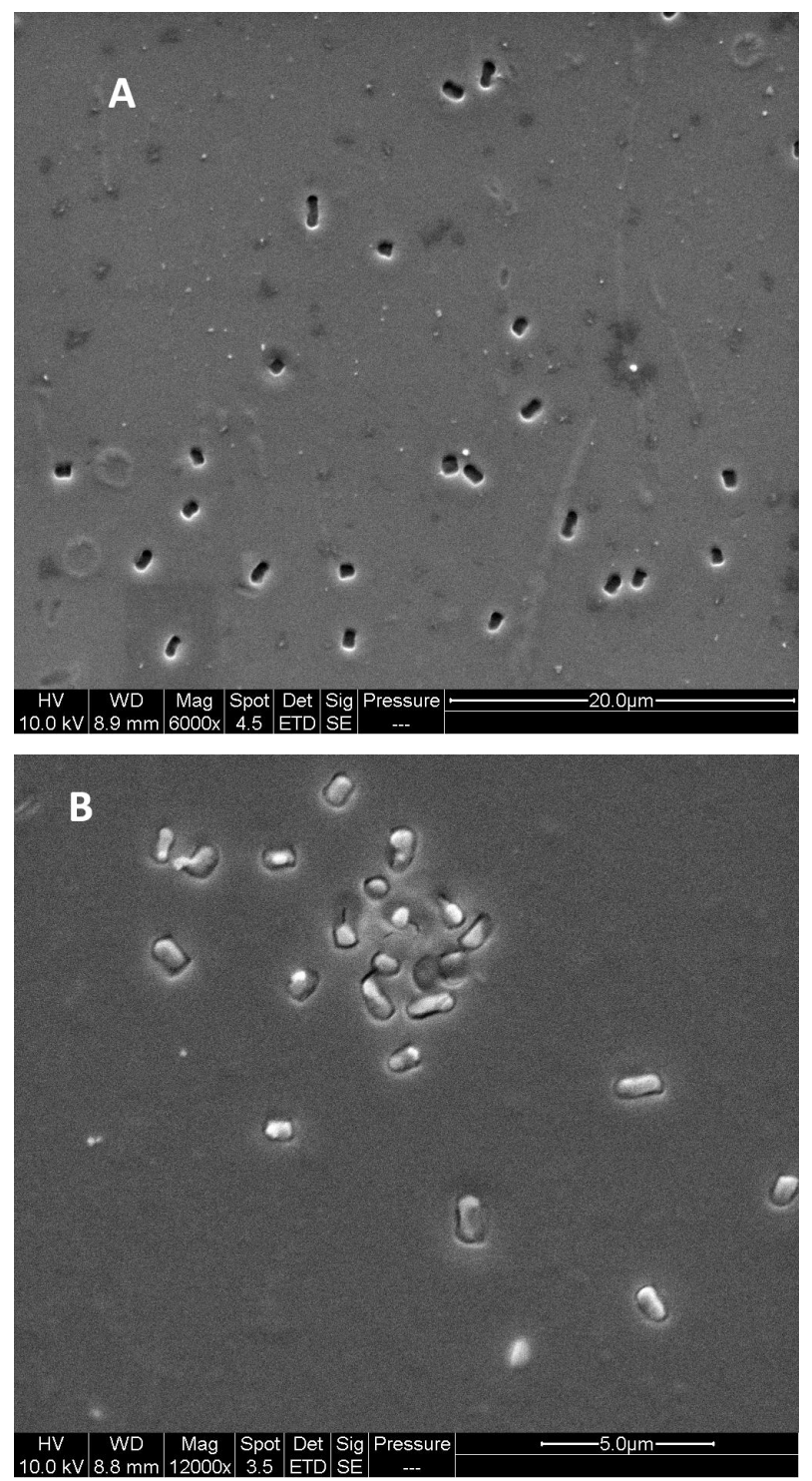

Figure 1. Scanning electron microscope (SEM) micrographs of sol-gel coats. (A) Cavities of an imprinted sol-gel film with $S$. natans; (B) Imprinted sol-gel film exposed to $S$. natans suspension after cells adsorption (note: only cavities' specific adsorption).

order to find out the impact of different physical parameters on the adsorption of test bacteria on the imprinted sol-gel films. Two closely related bacteria $(E$. coli $\mathrm{O} 157: \mathrm{H} 7$ and S. typhimurium) were imprinted onto sol-gel films made on microscope glass-slides in order to investigate the capability to discriminate between the two strains by the macromolecular imprinting method and further detected by immunofluorescence (Figures 2 and 3). Figure 2 shows E. coli O157:H7 imprinted slides observed through three laser channels (1-green channel, 2red channel and 3-green and red merged) including challenge with $S$. typhimurium. Slide with the template bacteria is shown by $(\mathrm{A})$; the same slide after template
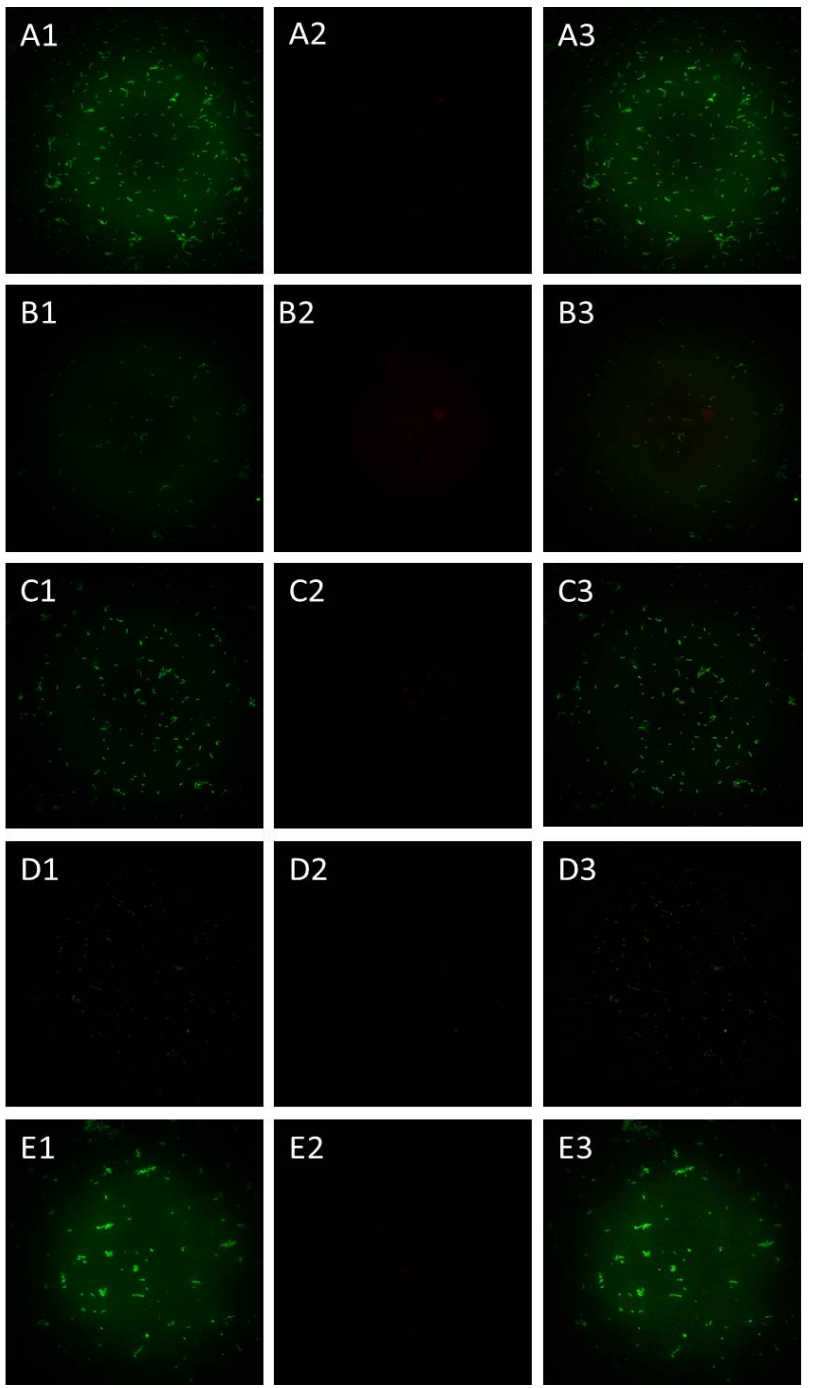

Figure 2. E. coli O157:H7 imprinted films-(1) Green channel, (2) red channel and (3) merged channel. (A) refers to bacteria in the film; (B) is imprinted film; (C) imprinted film after re-adsorption with E. coli $0157: H 7$; (D) imprinted film after re-adsorption with $S$. typhimurium; and (E) refers to imprinted film after re-adsorption of mixed suspension of both bacteria types. Bacteria were detected by specific antibodies: $E$. coli $0157: H 7$ antibody was conjugated with FITC (green fluorescence) and $S$. typhimurium antibody was conjugated to DyLight $594^{\odot}$ (red fluorescence). All samples were exposed to both antibodies.

removal is shown in (B); (C) and (D) represents these slides after re-adsorption of template bacteria $E$. coli O157:H7 and with S. typhimurium separately and (E) with mixed suspension of both bacterial types. Green rods detected with CLSM reveal that slides imprinted with E. coli O157:H7 allow re-adsorption of this E. coli O157:H7 exclusively. In order to verify the observed selectivity, the same procedure was performed but this time with slides imprinted with $S$. typhimurium and challenged with both bacterial types: S. typhimurium and E. 
coli O157:H7 (Figure 2). Figures 2 and $\mathbf{3}$ demonstrate that the method of sol-gel macromolecular imprinting (with bacteria) could effectively differentiate between two very similar enteric bacteria: $S$. typhimurium and $E$. coli O157:H7. Sol-gel films imprinted with E. coli O157: $\mathrm{H} 7$ showed no adsorption of $S$. typhimurium either unaccompanied and also when in mixed suspension with $E$. coli (Figures 2(D) and (E) series), while revealing high affinity towards E. coli cells (Figures 2(C) and (E) series). The opposite was observed with $S$. typhimurium imprinted films revealing sole affinity towards $S$. typhimurium cells with no re-adsorption of E. coli challenge (Figures 3(C) and (E)).

\subsection{Sensitivity of the Method for $E$. coli Detection Using QCM and Live Cell Imaging}

The main goal of the present study was to assess different physical parameters on bacterial cell adsorption onto imprinted sol-gel films. Comparison of both imprinting materials, polyurethane, used by Dickert et al. [15], and silica based sol-gel, used in the present research, displayed a substantial difference. The reported sensitivity of polyurethane was found to range between $10^{4}$ to $10^{6}$ $\mathrm{CFU} / \mathrm{ml}$. In the current study using an alkoxide polymer (TEOS) a greater sensitivity has been achieved. The sensitivity of imprinted alkoxide polymer with bacteria, has been investigated as a function of cell concentration (CFU/ml) by CLSM bright-field scan and QCM measurements.

Figure 4 shows the difference between imprinted solgel film and non-imprinted one observed by QCM measurements. After rinsing the coated crystals, both were exposed to saline solution containing $10^{7}$ cells $/ \mathrm{ml}$ of $E$. coli $\mathrm{CN}_{13}$ bacteria. The non-imprinted film showed minor reaction to the bacterial suspension that can be attributed to organic matter and metabolites that adsorbed nonspecifically on the sol-gel film, impacting weight measurements. The imprinted film showed a great decrease in $\Delta \mathrm{F}$ (resonant frequency shift), which implies on a massive change in the weight implemented on the crystal, especially in comparison to $\Delta \mathrm{F}$ obtained with the nonimprinted film. The whole-bacteria adsorption was only specific for imprinted films, while non-imprinted TEOS films adsorption is virtually non-existent as previously described by Cohen et al. [7].

Imprinted TEOS thin films can detect E. coli at numbers as low as $10^{2}$ to $10^{3} \mathrm{CFU}$ as can be seen from the QCM measurements (Figure 5). This method sensitivity was further substantiated by CLSM bright-field scan (Figures 6 and 7).

Figure 6 demonstrates the correlation between cell concentration and adsorption rate, as observed with
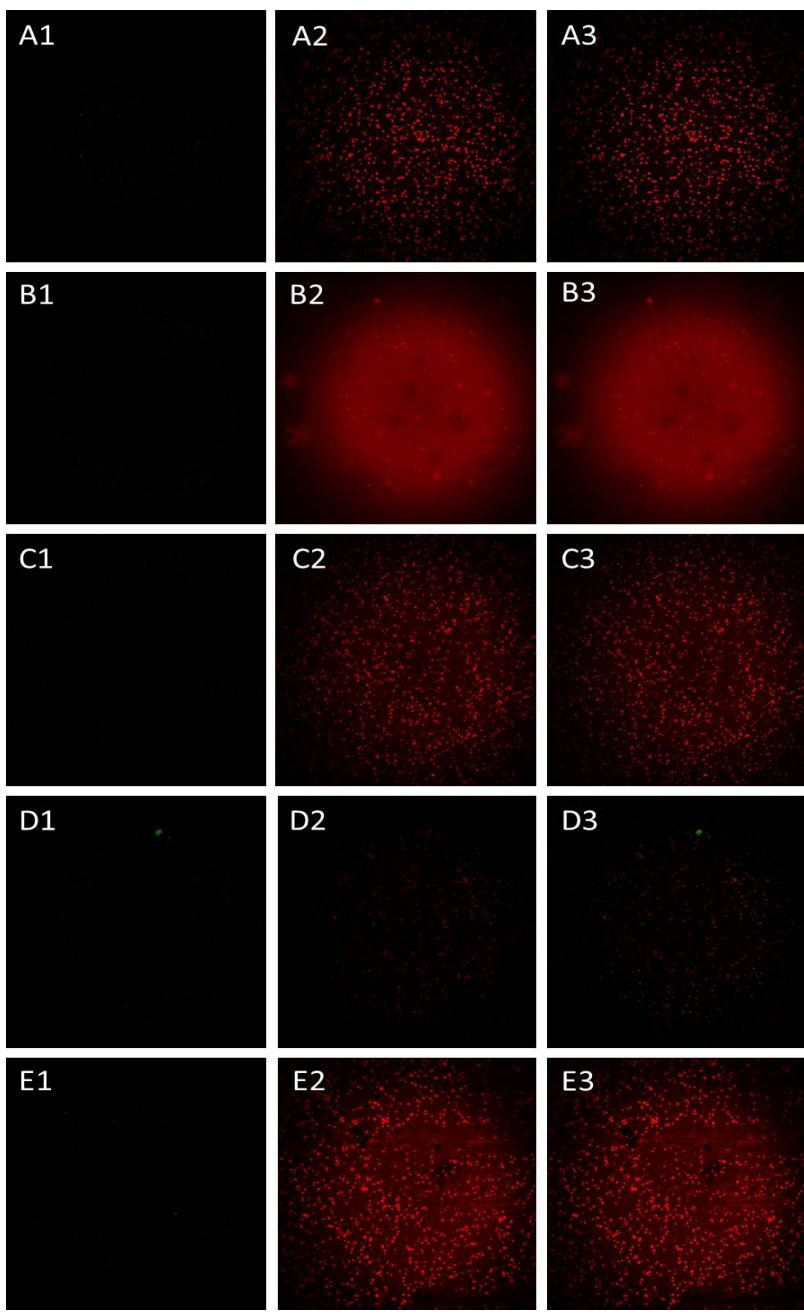

Figure 3. S. typhimurium imprinted films-(1) Green channel, (2) red channel and (3) merged channel. (A) refers to bacteria in the film; (B) is imprinted film; (C) imprinted film after re-adsorption $S$. typhimurium; (D) imprinted film after re-adsorption with $E$. coli $0157: H 7$; and (E) refers to imprinted film after re-adsorption of mixed suspension of both bacteria types. Bacteria were detected by specific antibodies: $E$. coli O157:H7 antibody was conjugated with FITC (green fluorescence) and $S$. typhimurium antibody was conjugated to DyLight $594^{\circ}$ (red fluorescence). All samples were exposed to both antibodies.

CLSM using live cell imaging. In this experiment, different cell concentrations were applied and specific adsorption was monitored for one hour (pictures were taken every 30 seconds). The adsorbed cells in each frame were counted and normalized to the initial number of imprinted cavities counted on the first frame.

From CLSM experiments as well as from the parallel QCM measurements, the correlation between cell concentration and re-adsorption rate is obvious. The higher the solution cells concentration the higher the rate of re-adsorption. Since a volume of $1 \mathrm{ml}$ of cell suspension was diluted in $5 \mathrm{ml}$ of saline, the sensitivity here is even 


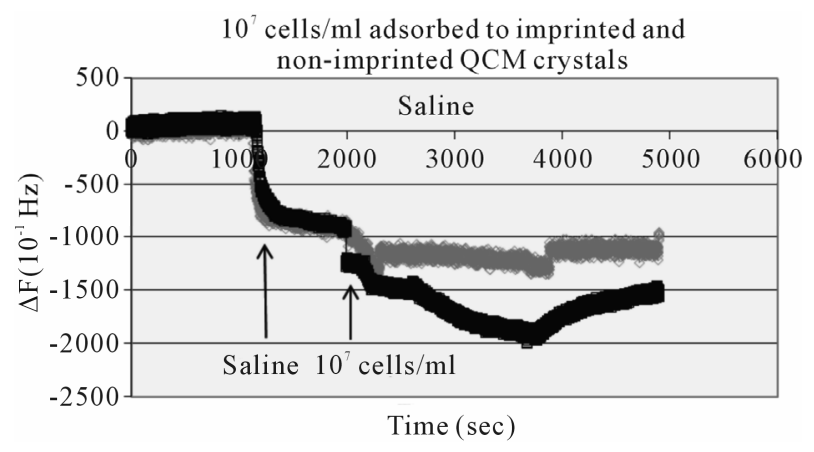

Figure 4. E. coli specific adsorption onto SG imprinted films as detected by QCM. Black line refers to SG film imprinted with $E$. coli bacteria and cells elution; gray line refers to control (non-imprinted sol-gel film) exposed to the same $E$. coli suspension.

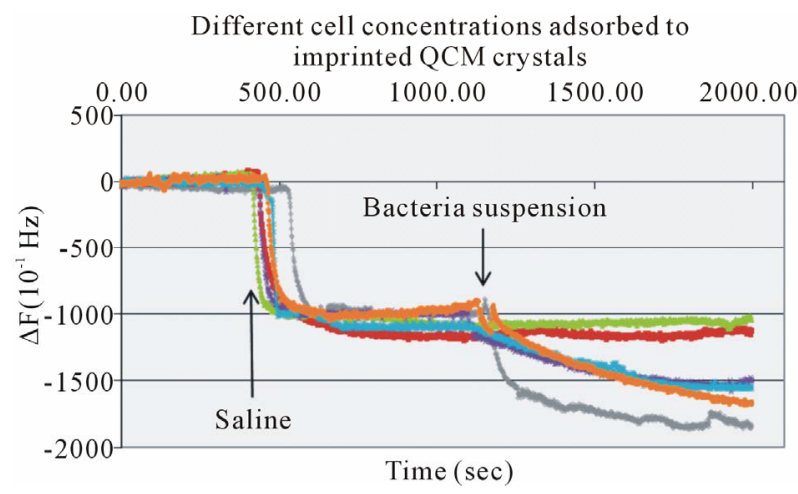

Figure 5. E. coli specific adsorption at different concentrations onto SG imprinted films (with $E$. coli) detected by QCM: Red line -0 cells $/ \mathrm{ml}$; green line -30 cells $/ \mathrm{ml}$; purple line-3 $3 \times 10^{2}$ cells $/ \mathrm{ml}$; blue line- $3 \times 10^{3}$ cells $/ \mathrm{ml}$; orange line $-3 \times 10^{4}$ cells $/ \mathrm{ml}$; gray line $-3 \times 10^{6}$ cells $/ \mathrm{ml}$.

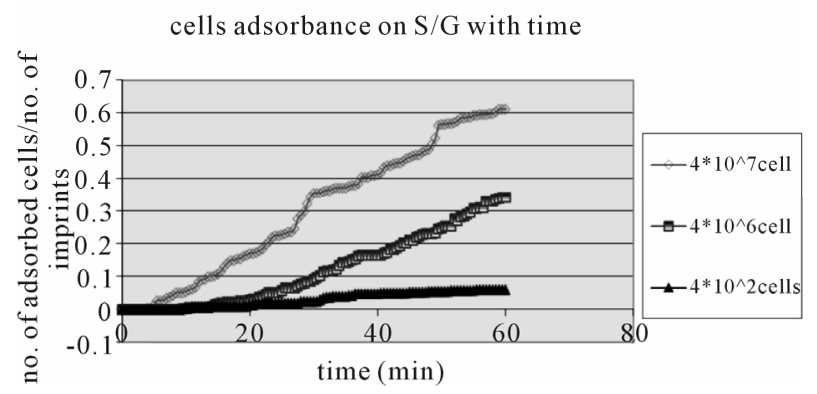

Figure 6. Specific adsorption kinetics of $E$. coli $\mathrm{CN}_{13}$ cells to imprinted slide, normalized to the initial number of imprinted cavities as observed with CLSM bright-field scan.

lower than $10^{2}$ cells $/ \mathrm{ml}$, and should be as low as 80 cells/ $\mathrm{ml}$.

\section{3. pH Effect on Bacterial Cell Adsorption onto Imprinted Sol-Gel Film}

Many ions are associated with normal cellular growth and development. Simple inorganic and organic ions establish both $\mathrm{pH}$ and ionic strength of a given system [21]. The overall metabolic function of these ions can be complex, but certain effects are distinct by the ability of such compounds to permeate cell walls, regulate osmotic pressure, facilitate transport and alter surface electrical charges [22]. These effects can be observed microscopically through changes in cell shape and size, or by their interaction with other cells and surfaces. As shown in Figure 7, solution's $\mathrm{pH}$ has great influence on adsorption, most likely as a consequence of changes in the zeta potential of the outer membrane [22]. The $\mathrm{pH}$ values for optimum adsorption depend on the relative isoelectric points of the microbial cell and the surface. In general, under physiological conditions, the optimal adsorption of bacterial cells onto surfaces occurs at $\mathrm{pH}$ range of 3 to 6 [21]. The results presented in Figure 7 reveal better readsorption equally in rate and in sheer numbers, at physiological $\mathrm{pH}$ of $\sim 7$.

\subsection{Organic Matter Effect on Bacterial Cell Adsorption onto Imprinted Sol-Gel Film}

Stark et al. [23] found that measurable amounts of organic matter accumulate within a few hours on chemically clean glass slides immersed in lake water. They expressed the concept that the accumulation of organic nutrients (conditioning film) favors bacterial growth. Supporting evidence is given by the studies on the relation between food concentration and solid surfaces [24]. Specific structures such as fimbriae [25] and pili [26] may be involved in attachment to specific substrates. However, in aqueous environments adhesion is believed to be mediated by extracellular polymers $[27,28]$. The extent to which the polysaccharides are involved in the adhesion process is however open to query. Some reports suggest their roles both in the initial, reversible phase of adhesion $[29,30]$ and also in the later, irreversible phase $[21,27,30]$. Brown et al. [31] presented evidence suggesting that excess polymer production may even prevent adhesion, although trace amounts of polysaccharide might be initially required. Although this work does not involve biofilm formation and EPS production by the re-adsorbed bacteria, the role of organic matter in general

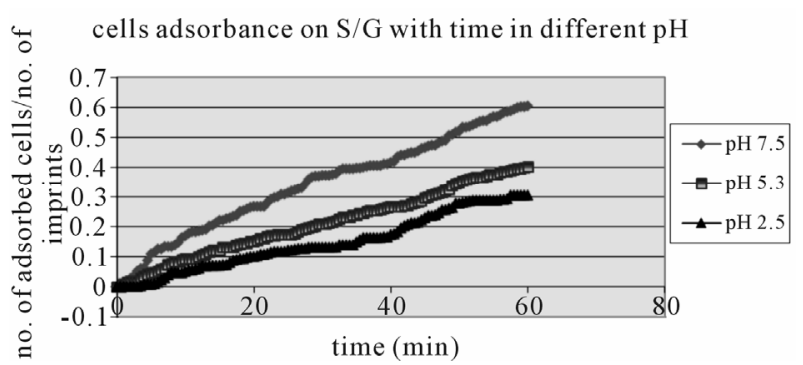

Figure 7. Effect of solution pH on $E$. coli $\mathrm{CN}_{13}$ re-adsorption on imprinted TEOS films. 
and cell envelope remnants on re-adsorption appears to be of great importance. As described previously, imprints of template cells contain proteins originating from cell membranes [7]. As can be seen in Figure 8, the total organic carbon (TOC) value higher than the one commonly recorded in drinking water $(>4 \mathrm{mg} / \mathrm{L})$ [32] appears to prevent re-adsorption onto imprinted film, while drinking-water levels of TOC (between 0.7 and $4 \mathrm{mg} / \mathrm{L}$ ) had no significant effect and re-adsorption occurred at the same rate as saline.

\subsection{Effect of $\mathrm{NaCl}$ Concentration on Cell Re-Adsorption}

The influence of electrolyte concentration on adsorption processes, is well documented. In any water suspension, a certain potential exists between charged particles and bulk medium, therefore counter-ions are attracted to surface to form a diffusible double layer of ions.

The thickness of the double layer is a function of the concentration (m-molar) and valency $(\mathrm{Z})$ of the electrolytes in solution. Double-layer thickness $(1 / \mathrm{k})$ is given by the equation $\mathrm{k}=3.27 \times 10^{7} \mathrm{ZM}^{1 / 2}$ [33]. In the present study, k equals $1.79 \times 10^{7}$ for $300,1.22 \times 10^{7}$ for $140 \mathrm{mM}$ and $1.22 \times 10^{6}$ for $1.4 \mathrm{mM}$ of a $\mathrm{NaCl}$ solution. The repulsive force encountered by a particle as it approaches a surface is a function of the double layer thickness.

Bacterial attachment is generally reported to increase under electrolytes at low ionic strengths $(0$ to $0.1 \mathrm{M})$. At higher ionic strengths, such as those found in estuarine or marine waters, an attachment decline versus increasing salt concentration was generally observed [34]. Studies had also showed that salt solutions will reduce adsorption and increase desorption of some bacteria from ion-exchange resins also through electrolytes bound to adsorption complex [35,36]. Addition of various inorganic salts to a water suspension may prevent adsorption and promote desorption from solid surfaces. Salts such as sodium chloride promote desorption, if adsorption had not became irreversible. Figure 9 demonstrates that sodium chloride concentrations above $140 \mathrm{mM}$ prevent cell adsorption onto imprinted sol-gel surface (isotonic and hypotonic solutions having no effect on cell re-adsorption).

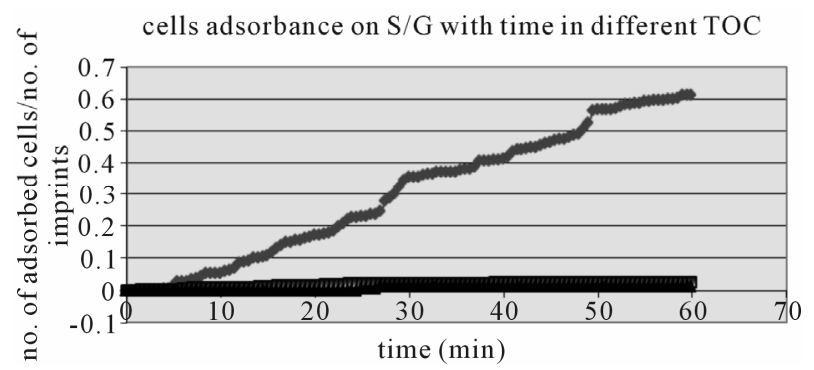

Figure 8. Effect of total organic content in the solution on $E$. coli $\mathrm{CN}_{13}$ re-adsorption on TEOS imprinted films.
Finally, in order to assess the feasibility of the present method to detect and identify microorganisms in drinking water in real time, QCM measurements of E. coli $\mathrm{CN}_{13}$ re-adsorption onto imprinted films of TEOS sol-gel were performed. As shown in Figure 10, albeit tap water has a greater background compared to saline, a distinct decline in $\Delta \mathrm{F}$ was evident following bacteria suspension introduction. This $\Delta \mathrm{F}$ shift indicates that most tap water parameters (e.g. salts, organic matter, trace metals etc.) have little effect on bacterial re-adsorption, therefore through re-adsorption specific bacteria can be specifically and rapidly detected in tap water (when present).

\section{Conclusions}

In the present study different parameters that may influence re-adsorption of bacteria onto previously imprinted sol-gel films were studied. Ormosil (such as TEOS) imprinted with various enteric bacteria revealed a highly specific cell adsorption following exposure to planktonic cells in saline suspensions. The high affinity of imprinted sol-gel films towards planktonic cells was previously found to be determined by cavity morphology (rod, coccus or tetrad) and residual components if the microorganism's outer surface was entrapped into the cavity surface area [7]. These two characteristics were found to be

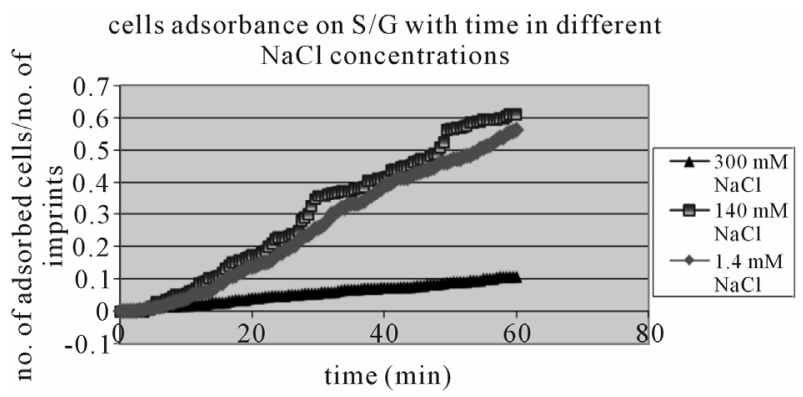

Figure 9. Effect of different $\mathrm{NaCl}$ concentrations in solution on $E$. coli $\mathrm{CN}_{13}$ re-adsorption on TEOS imprinted films.

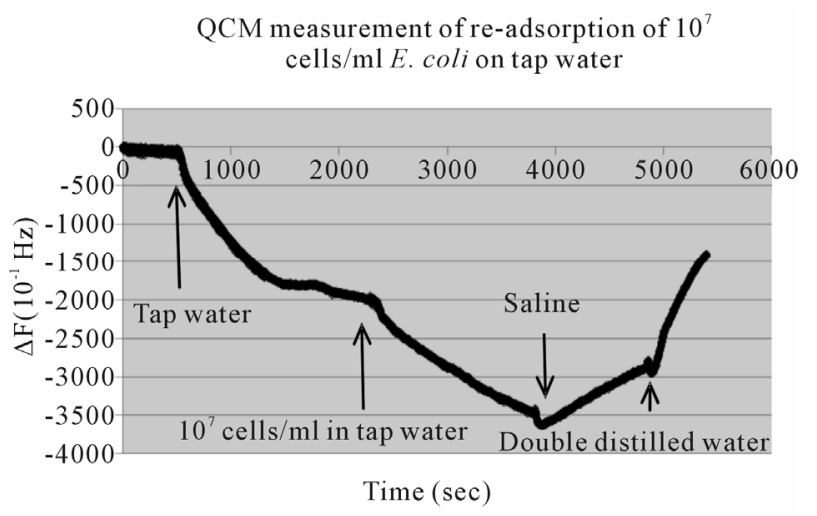

Figure 10. Re-adsorption of $E$. coli $\mathrm{CN}_{13}\left(10^{7}\right.$ cells $\left./ \mathrm{ml}\right)$ on imprinted TEOS thin films in tap water, measured by QCM. 
specific enough to discriminate between the various bacteria tested without interference between the different species when mixed together. Therefore the bacterial type is of great importance and even bacteria strains that have many similar properties (i.e. enterobacteriaceae) do not re-adsorb to cavities other than their own imprints. The method is consequently specific enough to differentiate between different bacteria. Application of QCM and CLSM bright-field scans revealed improved sensitivity of this recognition method compared with previous results published by Dickert et al. [14,15]. Concentrations as low as $10^{2} \mathrm{CFU} / \mathrm{ml}$ were detectable on QCM, and an even lower concentration $(80 \mathrm{CFU} / \mathrm{ml})$ was detectable with CLSM. The present study results have showed that water various parameters may influence re-adsorption onto imprinted sol-gel films (i.e. ionic strength, $\mathrm{pH}$ and total organic carbon (TOC)). Among these parameters, TOC showed a significant effect on the extent of bacterial cells re-adsorption. Application of this method for drinking water must consider these parameters for its successful implementation. However under normal conditions, such as potable water the method revealed high sensitivity and fast results.

For further development of macromolecular imprinting method as a scientific tool for rapid examination of water samples to rapidly detect indicator and pathogenic bacteria, additional research is necessary related to commercial aspects of these imprinted films [37]. For instance the shelf-life of the imprinted SG films that is currently unknown. In the present research, SG films were used not late than two weeks after preparation, therefore establishing their shelf life is very much required.

\section{Acknowledgements}

The authors would like to thank the "Phyllis and Joseph Gurwin Fund for Scientific Advancement at the Technion" for its financial support of the present study and to Dr. Moshe Herzberg (Ben-Gurion University) for his help on QCM application.

\section{REFERENCES}

[1] C. J. Woodall, "Waterborne Disease-What Are the Primary Killers?" Desalination, Vol. 248, No. 1-3, 2009, pp. 616-621. doi:10.1016/j.desal.2008.05.110

[2] American Public Health Association, American Water Works Association and Water Pollution Control Federation, "Standard Methods for the Examination of Water and Wastewater," 21st Edition, American Public Health Association, Washington, 2005.

[3] V. C. A. Junqueira, R. C. Neto, N. da Silva and J. H. Terra, "Comparison of Methods for the Enumeration of Clostridium Perfringens Perfringens Spores in Water," Water Science and Technology, Vol. 65, No. 2, 2012, pp.

\section{7-232. doi:10.2166/wst.2012.758}

[4] W. J. Dore, K. Henshilwood and D. N. Lees, "Evaluation of F-Specific RNA Bacteriophage as a Candidate Human Enteric Virus Indicator for Bivalve Molluscan Shellfish," Applied and Environmental Microbiology, Vol. 66, No. 4, 2000, pp. 1280-1285.

doi:10.1128/AEM.66.4.1280-1285.2000

[5] Y. Kott and E. F. Glona, "Correlating Coliform Bacteria with Escherichia coli Bacteriophages in Shellfish," Water \& Sewage Works, Vol. 112, No. 11, 1965, pp. 424-426.

[6] J. M. Pisciotta, D. F. Rath, P. A. Stanek, D. M. Flanery and V. J. Harwood, "Marine Bacteria Cause False-Positive Results in the Colilert-18 Rapid Identification Test for Escherichia coli in Florida Waters," Applied and Environmental Microbiology, Vol. 68, No. 2, 2002, pp. 539544. doi:10.1128/AEM.68.2.539-544.2002

[7] T. Cohen, J. Starosvetsky, U. Cheruti and R. Armon, "Whole Cell Imprinting in Sol-Gel Thin Films for Bacterial Recognition in Liquids: Macromolecular Fingerprinting," International Journal of Molecular Sciences, Vol. 11, No. 4, 2010, pp. 1236-1252. doi:10.3390/ijms11041236

[8] K. Mosbach, "Molecular Imprinting," Trends in Biochemical Sciences, Vol.19, No. 1, 1994, pp. 9-14. doi:10.1016/0968-0004(94)90166-X

[9] K. Mosbach and O. Ramström, "The Emerging Technique of Molecular Imprinting and Its Future Impact on Biotechnology," Nature Biotechnology, Vol. 14, No. 2, 1996, pp. 163-170. doi:10.1038/nbt0296-163

[10] G. Carturan, R. Campostrini, S. Diré, V. Scardi and E. De Alteriis "Inorganic Gels for Immobilization of Biocatalysts: Inclusion of Invertase-Active Whole Cells of Yeast (Saccharomyces Cerevisiae) into Thin Layers of $\mathrm{SiO}_{2} \mathrm{Gel}$ Deposited on Glass Sheets," Journal of Molecular Catalysis, Vol. 57, No. 1, 1989, pp. L13-L16. doi:10.1016/0304-5102(89)80121-X

[11] J. Y. Barreau, J. M. Da Costa, I. Desportes, J. Livage, L. Monjour and M. Gentilini, "Fixation and Immunological Reactivity of Parasitic Protozoa in Sol-Gel Matrices," Proceedings of the French Academy of Science, Series III, Life Sciences, Vol. 317, No. 7, 1994, pp. 653-657.

[12] J. Livage, C. Roux, J. M. Da Costa, I. Desportes and J.F. Quinson, "Immunoassays in Sol-Gel Matrices," Journal of Sol-Gel Science and Technology, Vol. 7, No. 1-2, 1996, pp. 45-51. doi:10.1007/BF00401882

[13] J. U. Chia, F. Tamanoi and B. J. I. Z. Dunn, "Patterned Hexagonal Arrays of Living Cells in Sol-Gel Silica Films," Journal of the American Chemical Society, Vol. 122, No. 27, 2000, pp. 6488-6489. doi:10.1021/ja0011515

[14] F. L. Dickert and G. Hayden, "Bioimprinting of Polymers and Sol-Gel Phases. Selective Detection of Yeasts with Imprinted Polymers," Analytical Chemistry, Vol. 74, No. 6, 2002, pp. 1302-1306. doi:10.1021/ac010642k

[15] F. L. Dickert, P. Lieberzeit and O. Hayden, "Sensor Strategies for Microorganism Detection-From Physical Principles to Imprinting Procedures," Analytical and Bioanalytical Chemistry, Vol. 377, No. 3, 2003, pp. 540-549. 


\section{doi:10.1007/s00216-003-2060-5}

[16] O. Hayden, C. Haderspock and F. L. Dickert, "Microorganism Detection with Selective Bioimprinted Polymers and Sol-Gels," International Journal of Bio-Chromatography, Vol. 6, No. 4, 2001, pp. 303-311.

[17] S. G. Andrews and F. J. Millero, "Electrolyte Effects on Attachment of an Estuarine Bacterium," Applied and Environmental Microbiology, Vol. 47, No. 3, 1984, pp. 495499.

[18] R. Armon, M. Arella and P. Payment, "A Highly Efficient Second-Step Concentration Technique for Bacteriophages and Enteric Viruses Using Ammonium Sulfate and Tween 80," Canadian Journal of Microbiology, Vol. 34, No. 5, 1988, pp. 651-655.

[19] D. Avnir, "Organic Chemistry within Ceramic Materials: Doped Sol-Gel Materials," Accounts of Chemical Research, Vol. 28, No. 8, 1995, pp. 328-334. doi:10.1021/ar00056a002

[20] R. Zusman, C. Rotman, M. Ottolenghi and D. Avnir, "Doped Sol-Gel Glasses as Chemical Sensors," Journal of NonCrystalline Solids, Vol. 122, No. 1, 1990, pp. 107-109. doi:10.1016/0022-3093(90)90232-B

[21] G. Bitton and K. C. Marshall, "Adsorption of Microorganisms to Surfaces,” Wiley-Interscience, Weinheim, 1980.

[22] C. E. Zobell, "The Effect of Solid Surfaces upon Bacterial Activity," Journal of Bacteriology, Vol. 46, No. 1, 1943, pp. 39-56.

[23] W. H. Stark, J. Stadler and E. McCoy, "Some Factors Affecting the Bacterial Population of Freshwater Lakes," Journal of Bacteriology, Vol. 36, No. 1, 1938, pp. 653654.

[24] H. Heukelekian and A. Heller, "Relation between Food Concentration and Surface for Bacterial Growth," Journal of Bacteriology, Vol. 40, No. 4, 1940, pp. 547-558.

[25] M. Rosenberg, E. A. Bayer, J. Delarea and E. Rosenberg, "Role of Thin Fimbriae in Adherence and Growth of Acinetobacter Calcoaceticus RAG-1 on Hexadecane," Applied and Environmental Microbiology, Vol. 44, No. 4, 1982, pp. 929-937.

[26] R. L. Weiss, "Attachment of Bacteria to Sulphur in Extreme Environments," Journal of General Microbiology, Vol. 77, No. 2, 1973, pp. 501-507.

[27] M. Fletcher and G. D. Floodgate, "An Electron-Micro- scope Demonstration of an Acidic Polysaccharide Involved in the Adhesion of a Marine Bacterium to Solid Surfaces," Journal of General Microbiology, Vol. 74, No. 2, 1973, pp. 325-334.

[28] G. G. Geesey, W. T. Richardson, H. G. Yeomans, R. T. Irvin and J. W. Costerton, "Microscopic Examination of Natural Sessile Bacterial Populations from an Alpine Stream," Canadian Journal of Microbiology, Vol. 23, No. 2, 1977, pp. 1733-1736.

[29] W. A. Corpe, "Attachment of Marine Bacteria to Solid Surfaces," In: R. S. Manley, Ed., Adhesion in Biological Systems, Academic Press, New York, 1970, pp. 73-87.

[30] M. Fletcher, "The Attachment of Bacteria to Surfaces in Aqueous Environments," In: D. C. Ellwood, J. Melling and P. Rutter, Eds., Adhesion of Microorganisms to Surfaces, Academic Press, London, 1979, pp. 88-108.

[31] C. M. Brown, D. C. Ellwood and J. R. Hunter, "Growth of Bacteria at Surfaces: Influence of Nutrient Limitation," FEMS Microbiology Letters, Vol. 1, No. 3, 1977, pp. 163-166.

[32] I. T. Miettinen, T. Vartiainen and P. J. Martikainen, "Phosphorus and Bacterial Growth in Drinking Water," Applied and Environmental Microbiology, Vol. 63, No. 8, 1997, pp. 3242-3245.

[33] S. G. Andrews and F. J. Millero, "Electrolyte Effects on Attachment of an Estuarine Bacterium," Applied and Environmental Microbiology, Vol. 47, No. 3, 1984, pp. 495-499.

[34] T. Kaneko and R. R. Colwell, "Adsorption of Vibrio Parahaemolyticus onto Chitin and Copepods," Applied Microbiology, Vol. 29, No. 2, 1975, pp. 269-274.

[35] S. L. Daniels, "The Adsorption of Microorganisms onto Solid Surfaces: A Review," Developments in Industrial Microbiology Series, Vol. 13, 1972, pp. 211-253.

[36] J. Wood, "Interaction of Micro-Organisms with Ion Exchange Resins," In: R. C. W. Berkeley, J. M. Lynch, J. Melling, P. R. Rutter and B. Vincent, Eds., Microbial Adhesion to Surfaces, Ellis-Horwood, West Sussex, 1980, pp. 163-186.

[37] T. Takeuchi, T. Mukawa and H. Asanuma, "Molecular Imprinting from Fundamentals to Applications," WileyVCH, Weinheim, 2003. 